\title{
Methods for evaluation of "in situ" coal permeability in underground coal mines using hydrodynamic test data
}

The paper presents methods for in situ evaluation of coal permeability paying special attention to methods invented in the Oil and Gas Institute - National Research Institute (INiG - PIB). Included are:

- a slug test method and alternative interpretation of slug test data using procedure devised in INiG - PIB,

- a method which uses injection of water with a constant flow rate into a horizontal drainage well and accounts for the three dimensional flow (invented in INiG - PIB),

- a method which uses air pressure decay in an isolated segment of a horizontal/vertical well to calculate permeability and skin effect (invented in INiG - PIB).

Key words: permeability, skin effect, coal seam, hydrodynamic test, slug test, horizontal drainage well, compressed air.

\section{Metody określania przepuszczalności in situ w warunkach kopalnianych na podstawie wyników testów hydrodynamicznych}

\begin{abstract}
W artykule zaproponowano szereg metod przystosowanych do użytku w warunkach kopalnianych do określania przepuszczalności in situ węgli. Szczególną uwagę poświęcono metodzie interpretacji danych slug testu opracowanej w Instytucie Nafty i Gazu - Państwowym Instytucie Badawczym (INiG - PIB) oraz metodom zatłaczania wody do drenażowego odwiertu poziomego przy utrzymywaniu stałego wydatku tłoczenia uwzględniającym przepływ sferyczny, jak również metodzie interpretacji przebiegu spadku ciśnienia gazu w izolowanym odcinku otworu drenażowego wykorzystującej urządzenie opracowane w Głównym Instytucie Górnictwa (GIG). Wszystkie wymienione metody opracowano w INiG - PIB.
\end{abstract}

Słowa kluczowe: przepuszczalność, skin efekt, pokład węgla, test hydrodynamiczny, slug test, poziomy otwór drenażowy, sprężone powietrze.

\section{Introduction}

Methane, which is regarded as the primary hazard during coal mining operations appears to be an important energy carrier provided it can be collected and used for power generation. Other energy carriers such as oil and natural gas are rather scarce in Poland, which makes our economy totally dependent on coal.

The methane present in hard coal seams is a somewhat different energy carrier than gas contained within porous rocks, both as the gas composition and mechanism of gas storage are concerned. The methane fills pores and fractures of coal seams from where it can flow to the well in the same way as it does in standard porous rocks. On the other hand, the major portion of methane is adsorbed on surfaces of coal grains, from where it can be liberated if the pressure falls below the so called desorption pressure. Methane does not contain hydrogen sulphide, but it may contain some carbon dioxide and high molecular weight hydrocarbons like propane and butane - this makes it a valuable and environment friendly energy carrier.

The concentration of methane in coals and the accompanying explosion hazards, are an increasing trend because coal is being mined from increasingly deeper locations. The methane content of coal in the Upper Silesian Basin amounts to $30 \div 40$ standard cubic meters per one tonne and the gas release rate at the mining zone amounts to one hundred cubic meters per minute.

The coalbed methane reservoirs differ from conventional reservoirs because coal is both the reservoir rock and the source 
rock for methane. Coal is heterogeneous and anisotropic porous rock characterized by two porosity systems, i.e. macropores (cleats) and micropores (matrix).

In a macropore system the gas is compressed in a pore space and its' expansion provides energy for gas production. In coal reservoirs the majority of gas molecules are adsorbed at the surface of the coal grains. As the reservoir pressure is reduced, a gas is desorbed from the coal surface and flows through the system of fractures. Below are provided the major differences between conventional gas reservoirs and coal bed methane reservoirs. tional energy source because of the unconventional gas/coal binding mechanism. Methane flows through the pore space in the same way as in case of the standard porous rocks. On the other hand the methane molecules adsorbed on coal grain surfaces can be liberated by lowering pressure below the so called adsorption pressure. Coal itself is an unconventional gas collector, being a product of biochemical and geochemical processes aided by microorganisms.

Coal permeability is one of the most important factors from the viewpoint of methane production. The values of coal

\begin{tabular}{|l|l|l|}
\hline \multicolumn{1}{|c|}{ Characteristic } & \multicolumn{1}{|c|}{ Conventional } & \multicolumn{1}{c|}{ CBM reservoir } \\
\hline Gas generation & $\begin{array}{l}\text { Gas is generated in source rocks, then migrates } \\
\text { into the reservoir }\end{array}$ & Gas is generated and trapped within the coal \\
\hline Pore space & Randomly spaced fractures & Uniform cleats \\
\hline Gas storage mechanism & Gas is compressed within rock pore spaces & $\begin{array}{l}\text { Gas is stored by adsorption and compressed within the } \\
\text { pore space }\end{array}$ \\
\hline Transport mechanism & Gas pressure gradient (Darcy Law) & Concentration gradient and pressure gradient \\
\hline Production performance & $\begin{array}{l}\text { Gas rate declines, little or no water, GWR } \\
\text { (gas-water ratio) decreases within time }\end{array}$ & $\begin{array}{l}\text { Gas rate increases with time, initial production is mostly } \\
\text { water, GWR (gas-water ratio) increases with time }\end{array}$ \\
\hline Mechanical properties & $\begin{array}{l}\text { Young's modulus } \sim 10^{4} \mathrm{MPa} \\
\text { Pore compressibility } \sim 10^{-4} \frac{1}{\mathrm{MPa}}\end{array}$ & $\begin{array}{l}\text { Young's modulus } \sim 10^{3} \mathrm{MPa} \\
\text { Pore compressibility } \sim 10^{-2} \frac{1}{\mathrm{MPa}}\end{array}$ \\
\hline
\end{tabular}

According to some authors the methane reserves of the Rybnik Coal District alone may amount to $150 \mathrm{bln} \mathrm{Nm}^{3}$.

Poland has large coal reserves. Some of them are actually not mined because of:

- intense inflow of water,

- large depth of deposition,

- high temperatures,

- unfavorable geological conditions,

- economical reasons.

Usually the engineers try to remove some of the methane before the coal mining is initiated. To aid the methane removal process horizontal drainage wells are drilled into the coal layers to collect the methane and transfer it to the surface for utilization. The horizontal drainage wells and the vertical wells are drilled from the surface or from underground overhead mining levels to initiate the coal degasification process.

The reasons for which methane is drained from coal are as follows:

- improvement of workers safety and mitigation of explosion hazards,

- ecological reasons (protection of the natural environment, reduction of gas emissions into the atmosphere, better pollution control),

- economical reasons (methane is a valuable energy source which can mitigate gas shortages in national economy). As mentioned earlier, the coalbed methane is an unconven- permeability provided in technical literature are from zero to a few milidarcy, and on average the permeability is very low. The permeability is a measure of ability to transfer gas or water through the coal matrix. It allows us to evaluate the potential of methane production from coal. The porosity of coals is also rather low and doesn't amount to much percentage-wise, providing volume of pores and microfractures is included in the porosity calculation. When methane is drained from coal the permeability and porosity are governed by two opposing mechanisms. On the one hand, the permeability and porosity decreases - which is caused by a decrease of reservoir pressure and an accompanying increase of overburden pressure exerted on the coal matrix (reservoir pressure and strength of rock matrix oppose the overburden pressure) and increases due to matrix shrinkage caused by methane desorption on the other hand.

Several tests are used for evaluation of coal permeability in underground mine conditions. Herein are presented tests procedures and methods of interpretation of test results for vertical and horizontal drainage wells. Some of the tests use water, and some, gas as the testing medium.

It should be emphasized that the hydrodynamic tests which use water are to be performed at the initial dewatering stage when one phase flow occurs within coal. The results of the water injection test carried out during the gas liberation stage may be misleading. 


\section{Test for coalbed methane wells - testing procedures and interpretation for vertical well - Slug test}

Usually large volumes of water must be removed from coal before gas production is initiated. Well tests are designed to determine the permeability of coals. At virgin reservoir conditions the coal seams are saturated with water and so the best moment to perform the test is prior to the start of the well production when the reservoir is totally $(100 \%)$ water saturated. Interpretation of tests after two-phase flow conditions are established may be misleading. In water saturated coals, the flow rate from the reservoir is controlled by its permeability. The flow rate of gas liberated from coal also depends on permeability along with several other factors.

The "slug test" is the most frequently used method for determination of coal bed permeability $[2,6,7]$. The advantages are the low cost and uncomplicated equipment required to run the test. The "slug test" is used at the early dewatering stage, when the water level has stabilized at some depth below the surface. The slug test involves the sudden removal or addition of some water from the well and then analyzing the water table behavior (or bottom hole pressure behavior), to determine the reservoir transmissibility. If the duration of the test is sufficiently long, the water will continue to accumulate in the well until the pressure exerted by the liquid column in the well, is equal to the reservoir pressure. When the standard slug test is used, the permeability and skin effect are evaluated by matching the measured pressure vs. time curve to a curve among the family of theoretical curves.

Conditions required for correct execution of the ,slug test" are as follows:

- the water level must be stabilized before some portion of water is removed from the well,

- the coal bed must be adequately isolated (only the coal seam is open to flow),

- a portion of the water must be removed as quickly as possible,

- the measurements of the water table level (or down hole pressure) vs. time during return to pressure equilibrium must be done precisely.

The results of the slug test interpretation do not depend on the volume of water removed from the well and the only requirement is to lower the level of the water table in the well. The simplest procedure to run a "slug test" is given below:

- run the blind tubing into the coal bed methane well and immerse it a dozen or so meters below the water level,
- wait until the water level reaches stabilization,

- quickly remove the tubing from the well to cause the water level to drop (maximum drop of the water level can be calculated if tubing size and immersed tubing length are known),

- start measuring the water table position (or down hole pressure) vs. time while the water table moves upward during pressure stabilization.

Next the following curves are constructed:

a) $p_{D} v s \cdot \log t$

b) $\log p_{D} v s \cdot \log t$

c) $\log \left(1-p_{D}\right) v s \cdot \log t$,

and fitted to one curve among family of theoretical curves (a to a', b to b' and so on) where:

a) $p_{D}$ vs. $\log \left(t_{D} / c_{D}\right)$ (fitting the whole curve a),

b) $\log p_{D} v s . \log \left(t_{D} / c_{D}\right)$ (fitting the initial portion of curve b), c) $\log \left(1-p_{D}\right) v s \cdot \log \left(t_{D} / c_{D}\right)$ (fitting the final portion of curve c), where $p_{D}$ is given by Eq. (1), $t_{D}$ is dimensionless time and $c_{D}$ is a wellbore storage coefficient.

The matching of curves is done by moving the measured curve horizontally over the theoretical ones and finding the two curves which fit best. The scale and length of the logarithmic cycle must be the same for the measured and theoretical curves. After curve fitting is done the "match point" is selected for which $t$ and $t_{D} / c_{D}$ are recorded plus $c_{D} e^{2 S}$ parameter of theoretical curve where $S$ is a skin factor. These recorded values are then used for the calculation of permeability and skin effect.

The mathematical model behind the slug test methods and assumed initial and boundary conditions are given in several papers (for example $[4,6,7]$ ). Later in the text we will provide an example of the slug test interpretation for one of coal methane wells in Zofiówka coal mine.

It should be emphasized that the "slug test" is a widely used and cost effective method for the evaluation of permeability and skin effect of coal seams. Advantages of this method were specified in an earlier part of this article:

In our opinion the "slug test" has one serious disadvantage i.e., the possible mismatching of curves, because all type curves look alike. Fitting the measured curve to the wrong theoretical curve may yield erroneous results which has been demonstrated on several examples.

\section{Method of interpretation of "slug test" data using INiG - PIB procedure}

As mentioned earlier, the presented method of slug test interpretation may yield erroneous results due to the mismatching of curves. The INiG - PIB procedure of running the test is the same as that used for the "slug test" method i.e. the following conditions must be satisfied:

- water table must be stabilized in the well, 
- only the coal seam is open to flow,

- some portion of water is removed from the well as quickly as possible.

It has been proven in paper [8] that the equation which relates to dimensionless pressure and time - during the fall or rise of the water table after water is removed or added to the well - has the following form:

$$
\ln p_{D}=-\frac{1}{* *} \frac{K h \rho g t}{r_{c}^{2} \mu}-\ln \left(1-\frac{S}{* *}\right)
$$

Where $p_{D}$ is given by:

$$
p_{D}=\frac{H(t)}{H_{0}}=\frac{p_{i}-p_{d}(t)}{p_{i}-p_{0}}
$$

${ }^{* *}$ is the root of the following equation:

$$
u=\frac{1}{2}(\log u-\log a)
$$

where:

$$
a=\frac{1}{2}\left(\frac{r_{o}}{r_{c}}\right)^{2} h \phi \rho g c_{t}
$$

$g-$ acceleration of gravity.

Equation (1) indicates that $\ln p_{D}$ vs. $t$ data should plot along the straight line with slope $E$ :

$$
E=-\frac{1}{* *} \frac{K h \rho g}{r_{c}^{2} \mu}
$$

and that this straight line intersects the ordinate axis for $t=0$ at point $D$ given by:

$$
D=-\ln \left(1-\frac{S}{u}\right)
$$

Knowing slope $E$ and $D$ the permeability $K$ and skin effect $S$ can be calculated.

When SI system is converted to units used in industry the Eq. (1) is given by:

$$
\begin{aligned}
& \operatorname{In} p_{D}=-(5.11)(10)^{-7} \frac{K[\mathrm{mD}] h[\mathrm{~m}] \rho\left[\frac{\mathrm{g}}{\left.\mathrm{cm}^{3}\right]} t[\mathrm{~min}]\right.}{r_{c}^{2}\left[\mathrm{~m}^{2}\right] \mu[\mathrm{cp}]} \frac{1}{\frac{* *}{u}} \\
&-\ln \left(1-\frac{S}{* *}\right) \\
& u
\end{aligned}
$$

and

$$
a=0.049\left[\frac{r_{o}}{r_{c}}\right]^{2} h[\mathrm{~m}] \phi \rho\left[\frac{\mathrm{gm}}{\mathrm{cm}^{3}}\right] c_{t}\left[\frac{1}{\mathrm{MPa}}\right]
$$

The value at $u^{* *}$ is calculated using simple iteration procedure shown in detail in paper [8].

The values of permeability $K$ and skin effect $S$ can be also calculated without the need for drawing the $\log p_{D} v s . t$ straight line using the formulas provided in [11].

$K=(1.95)(10)^{6} \frac{r_{c}^{2} \mu u}{h \rho}\left(\frac{\sum_{i=1}^{N} \log p_{D i} \sum_{i=1}^{N} t_{i}-N \sum_{i=1}^{N} t_{i} \log p_{D i}}{N \sum_{i=1}^{N} t_{i}^{2}-\left(\sum_{i=1}^{N} \ln t_{i}\right)^{2}}\right)$

where $N$ - number of $\log p_{D} v s . t_{i}$ data which plot along the straight line. As shown in [12] the INiG - PIB method may be also used for the calculation of the wellbore zone permeability and the extent of the zone with improved/impaired permeability around the wellbore. It has been demonstrated in paper [11] that the INiG - PIB method yields results which are very close to the results of "slug test" method.

Nowadays, both the "slug test" method and the INiG - PIB method are routinely used in our industry for calculation of permeability and skin effect and are considered as verified and reliable tools. Interpretation of test data using the INiG - PIB method is easier than the curve fitting method (slug test method) and the mismatching uncertainty is eliminated.

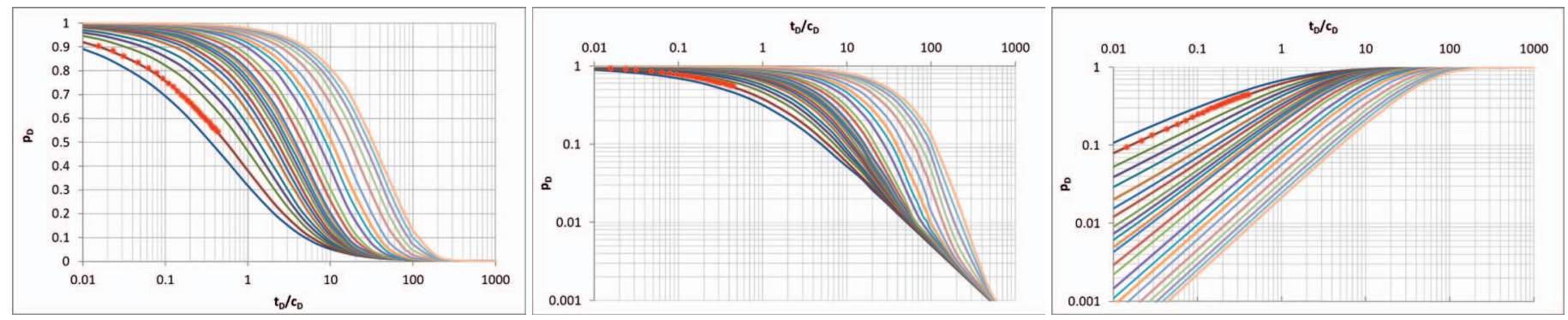

Fig. 1. Fitting the whole, initial and final portion of the test curve (red points) 
Table 1. Results of test interpretation using the ,slug test” method

\begin{tabular}{|l|c|c|}
\hline \multirow{2}{*}{$\begin{array}{c}\text { Match of test curve to } \\
\text { theoretical curves }\end{array}$} & Permeability & \multirow{2}{*}{ Skin effect } \\
\cline { 2 - 2 } & {$[\mathrm{mD}]$} & \\
\hline Whole curve & 0.1771 & -5.24 \\
\hline Initial portion of curve & 0.1778 & -5.24 \\
\hline Final portion of curve & 0.1826 & -5.24 \\
\hline
\end{tabular}

Below you will find examples of test data interpretation for a vertical coal bed methane well drilled in Zofiówka coal mine. The slug test method (Figure 1) and INiG - PIB method (Figure 2) were used and results were compared indicating negligible differences between the two.

As demonstrated in [12] the short time data in Figure 3 represents the wellbore zone permeability (fracture permeability), whereas the long time data indicates permeability of coal matrix. If so, the following values may be calculated for the above provided example using the INiG - PIB method:

- permeability of the wellbore (macro fracture) zone $-1.707 \mathrm{mD}$,

- permeability of coal matrix $-0.128 \mathrm{mD}$,

- skin effect $-S=-4.63$,

- depth of permeability impairment $-0.23 \mathrm{~m}$.

As shown, the results of the slug test and the INiG - PIB method are in acceptable agreement.

To verify the results of both methods the permeability of core samples collected at the fracture zone were measured in laboratory and the results are given in table 2 .

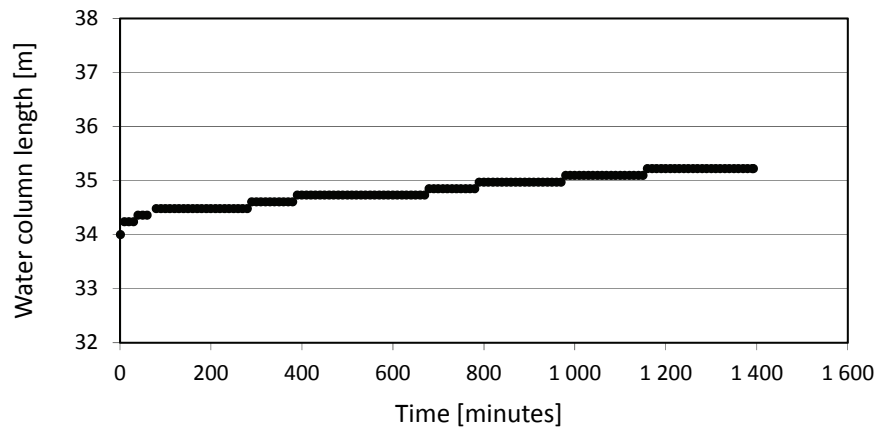

Fig. 2. Water column length vs. time

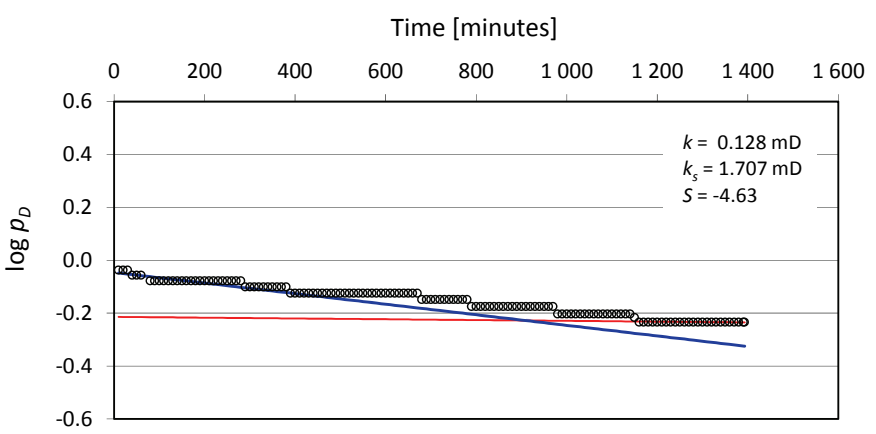

Fig. 3. $\log p_{D}$ vs. time

\begin{tabular}{|l|c|c|}
\hline \multicolumn{3}{|c|}{ Table 2. Fracture permeability of coal samples } \\
\hline \multicolumn{1}{|c|}{ Permeability } & Macro fracture & Micro fracture \\
\hline \multicolumn{1}{|c|}{$[\mathrm{mD}]$} & $(>0.1 \mathrm{~mm})$ & $(<0.1 \mathrm{~mm})$ \\
\hline Minimum & 1.25 & 1.32 \\
\hline Maximum & 2.08 & 14.73 \\
\hline Average & 1.42 & 4.37 \\
\hline
\end{tabular}

\section{Evaluation of coal permeability using water injection to the horizontal drainage well}

Horizontal drainage wells are drilled to reduce methane content in hard coals. If the coal is water saturated, the simple water injection test using equipment shown in Figure 4, can be used to determinate permeability and skin effect of coal matrix. This equipment is similar to the aerometric probe (shown in paper [5]), which is used to evaluate the degree of rocks compactness around the mining excavation. It consists of a pipe with two sealing packers and a small pump capable to maintain the constant flow rate of water. The pipe segment between packers is perforated to enable water flow into the coal matrix.

When water is pumped into the horizontal well (see Figure 4), it would probably flow horizontally through the fractured zone where permeability is the greatest. However, it is well documented by laboratory experiments [5], that the confining pressure drastically reduces permeability of fractured rock. Thus, we assume, that permeability of the wellbore zone opposite packers, is similar to that of coal massive due to high packer pressure and that the trajectories of flow lines, looks as depicted in Figure 4. It should be noted, that packers are rubber elements whose length

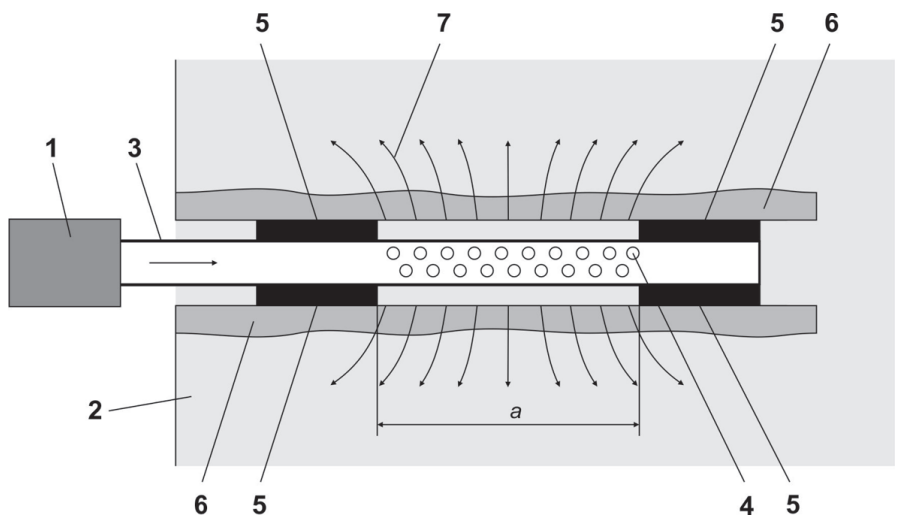

Fig. 4. Equipment for water injection test

1 - water pump with controlled flow rate, 2 - surrounding rocks (coal massive), 3 - pipe (blinded at the end), 4 - perforation openings,

5 - packers (inflatable by pressure of injected water), 6 - fractured wellbore zone, 7 - flow line trajectories

is about $0.5 \mathrm{~m}$. The equation which relates the water injection pressure and time was derived in paper [10]. It was assumed, that the coal bed is surrounded by impermeable layers from the 
top and bottom. The derived equation is rather inconvenient for well test interpretation purposes.

The simplified equation which we propose for the interpretation of water injection test in a horizontal well, is given below [10]:

$$
p_{i n j}(t)=p_{0}+\frac{Q \mu}{8 \pi a K}\left(\ln \frac{4 K t}{\gamma \phi \mu c r_{0}^{2}}+\bar{S}\right)
$$

Equation (10) works for the short time data and for the spherical flow of water. It is very similar to the one used in the oil industry for the interpretation of the liquid injection test to a vertical well when the radial flow is established. The skin effect $\bar{S}$ is included to Eq. (10) to account for fractured zone around the wellbore. The skin effect accounts for the additional pressure drop or pressure increase within the wellbore zone, caused by a different permeability of the wellbore zone and coal matrix. The physical meaning of $\bar{S}$ is somewhat different than $S$ used when radial flow occurs and is discussed in [11]. In units used in industry the equation (10) is given by:

$$
\begin{aligned}
& p_{\text {inj }}[\mathrm{MPa}]=p_{0}[\mathrm{MPa}]+39.81 \frac{Q\left[\frac{1}{\mathrm{~s}}\right] \mu[\mathrm{cP}]}{a[\mathrm{~m}] K[\mathrm{mD}]} \\
& \left(\ln t[\mathrm{~min}]+\ln \frac{K[\mathrm{mD}]}{\phi \mu[\mathrm{cP}] c\left[\frac{1}{\mathrm{MPa}}\right] r_{0}^{2}\left[\mathrm{~m}^{2}\right]}-8.912+\bar{S}\right)
\end{aligned}
$$

Equation (11) works for

$$
\begin{aligned}
& 4.16 \cdot 10^{3} \frac{\phi \mu[\mathrm{cP}] c\left[\frac{1}{\mathrm{MPa}}\right] r_{0}^{2}\left[\mathrm{~m}^{2}\right]}{K[\mathrm{mD}]} \leq t[\mathrm{~min}] \leq \\
& \leq 1.04 \cdot 10^{3} \frac{\phi \mu[\mathrm{cP}] c\left[\frac{1}{\mathrm{MPa}}\right] a^{2}\left[\mathrm{~m}^{2}\right]}{K[\mathrm{mD}]}
\end{aligned}
$$

As shown, Eq. (11) the $p_{i n j} v s$. Int data should plot along the straight line with slope $m$

$$
m=39.81 \frac{Q[1 / \mathrm{s}] \mu[\mathrm{cP}]}{a[\mathrm{~m}] K[\mathrm{mD}]}
$$

giving the value of permeability $K$. If the straight line is extended to $t=1 \mathrm{~min}$ and corresponding $p$ is recorded $\left(p_{i n j \lim }(t=1 \mathrm{~min})\right.$ then $\bar{S}$ is given by:

$$
\bar{S}=\left[\frac{p_{\text {inj }_{\mathrm{lim}}}(t=1 \mathrm{~min})-p_{0}}{m}-\ln \frac{K[\mathrm{mD}]}{\phi \mu[\mathrm{cP}] c\left[\frac{1}{\mathrm{MPa}}\right] r_{0}^{2}\left[\mathrm{~m}^{2}\right]}+8.912\right]
$$

Below you will find an example of the interpretation of the water injection test for a horizontal well using the presented method above [13] and data given in [14].

The plot of $p$ vs. $\log t$ is shown in Figure 5.

The remaining data are as follows:

- flow rate of water $Q=1.5 \mathrm{l} / \mathrm{s}$,

- water viscosity $\mu=1 \mathrm{cP}$,

- length of horizontal segment $a=305 \mathrm{~m}$,

- $\operatorname{porosity} \phi=0.2$,

- rock compressibility $c=(2.25) 10^{-3} 1 / \mathrm{MPa}$,

- well radius $r_{o}=0.0762 \mathrm{~m}$.

The calculated permeability and skin effect are equal $k=8.5 \mathrm{mD}, S=2.5$ respectively.

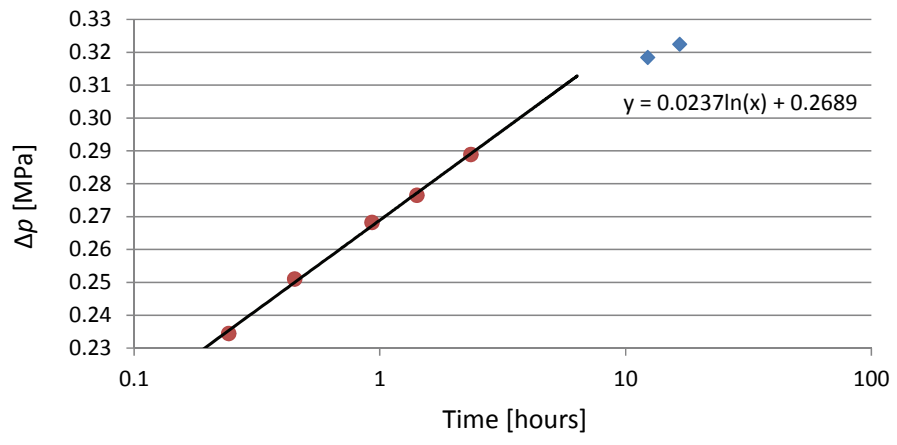

Fig. 5. Plot $\Delta p(t) v s$. time $t$

\section{Evaluation of in situ permeability of coal using aerometric probe and compressed air}

The permeability and skin effect of coal (and other porous rocks), can be easily evaluated in horizontal and vertical wells, using compressed air and the device shown in Figure 6.

According to [5] the measuring equipment consists of a pressure container (1) with capacity $V_{1}$ and probe which is composed of a pipe with pressure actuated sealing packers (3). The compressed air is transferred to the packers via special small diameter pipes (4) when the valve (5) is open. The pipe between packers is perforated to enable air flow into the coal. After the probe is installed in the well, the packers are actuated and valve (5) is closed. Next, the valve (6) is open for a while, to reduce the pressure in the container to some predetermined pressure $p_{1}$. Opening the main valve (7), allows the air to flow into the space between the packers and diffuse into the coal matrix through the perforation holes (8). The pressure gauge (9) is used to measure air pressure decay in container (1).

Opening the valve (7), causes a sudden increase of pressure in the isolated segment of the hole to $p_{1}$ level. Next, the pressure gradually decreases, until original reservoir pressure $p_{0}$ is attained which, theoretically, will happen after infinite time $t_{\infty}$. The equipment presented above is used by GIG to evaluate the following:

- total surface area of fractures at the wall of the isolated segment of a well, 
- total width of fracture "mouths" at the wall of the isolated segment of a well,

- so called fracture indicator. In practice, the test consists in measuring the time required for pressure to drop from $p_{1}=0.4 \mathrm{MPa}$ to $p=0.25 \mathrm{MPa}$. The empirical formulas are used to calculate the above given values.

It has been demonstrated in [14], that the data measured during such a test, are sufficient for rough approximation of permeability. The relation between the dimensionless pressure and time

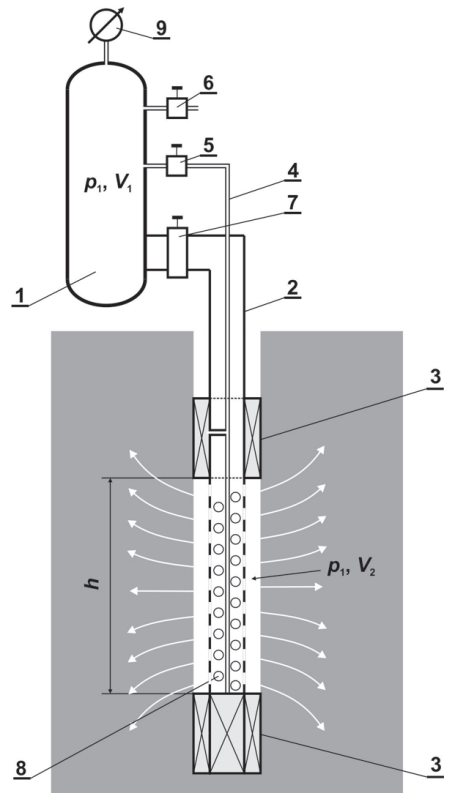

Fig. 6. Aerometric probe derived in [14], looks as follows:

$$
\begin{aligned}
\ln p_{D} & =\ln \frac{p\left(r_{0}, t\right)-p_{0}}{p_{1}-p_{0}}= \\
& =-\frac{2 \pi k h\left(p_{1}-p_{0}\right) t}{\mu_{g}\left(V_{1}+V_{2}\right) \ln \left(\frac{p_{1}}{p_{0}}\right)} \frac{1}{u}+\ln \left(1+\frac{S}{* *}\right)
\end{aligned}
$$

or using the engineering units:

$$
\begin{aligned}
\log p_{D}= & -1.2 \cdot 10^{-6} \frac{k[\mathrm{mD}] h[\mathrm{~m}]\left(p_{1}-p_{0}\right)[\mathrm{MPa}] t[\mathrm{~s}]}{\mu_{g}[\mathrm{cP}]\left(V_{1}+V_{2}\right)\left[m^{3}\right] \log \left(\frac{p_{1}}{p_{0}}\right)} \\
& \times \frac{1}{\stackrel{* *}{u}}+\log \left(1-\frac{S}{\stackrel{* *}{u}}\right)
\end{aligned}
$$

where $u$ is a root of the following equation:

$$
u e^{-2 u}=a
$$

where:

$$
a=\frac{V_{2} \phi c\left(p_{1}-p_{0}\right)}{2\left(V_{1}+V_{2}\right) \ln \frac{p_{1}}{p_{0}}}
$$

The $u$ is calculated using simple iteration procedure shown in detail in [8].
As seen from Eq. (16), the $\log p_{D} v s . t$ data should plot along the straight line which slope and intersection with $\log p_{D}$ axis will allow to calculate permeability and skin effect. If we assume that the pressure decay $v s$. time is such as given in [5] (time of pressure drop from 0.4 to $0.25 \mathrm{MPa}$ ) and that coordinates of this single measurement fits the straight $\operatorname{line}$ of $\log p_{D} v s . t$ relation - as indicated by Eq. (16), then it is possible to approximate the value of permeability using the method presented in [14]. Below you will find examples of permeability calculations for one of the Polish coal mines using data given in [5].

The approximated permeability values given in table 3 are rather high, but we should remember, that they refer to the wellbore zone where fractured coal may have really high permeability contrary to coal matrix which permeability is very low.

Using the method presented in [14], we analyzed data for four coal bed methane drainage wells. The achieved results are reasonable. We have no possibility for extensive verification of results because no laboratory data are available for analyzed fractured coals.

Table 3. Drainage well no. 1

\begin{tabular}{|c|c|c|c|}
\hline $\begin{array}{c}\text { Well } \\
\text { length }\end{array}$ & $\begin{array}{c}\text { Total surface } \\
\text { area of fractures } \\
\text { at the well wall } \\
\text { acc. to [12] }\end{array}$ & $\begin{array}{c}\text { Time required for } \\
\text { pressure to drop } \\
\text { from 0.40 MPa to } \\
0.25 \mathrm{MPa} \text { acc. to } \\
{[12]}\end{array}$ & $\begin{array}{c}\text { Permeability } \\
\text { of the wellbore } \\
\text { zone (fracture } \\
\text { permeability) }\end{array}$ \\
\hline$[\mathrm{m}]$ & {$\left[\mathrm{mm}^{2}\right]$} & {$[\mathrm{s}]$} & {$[\mathrm{mD}]$} \\
\hline 1.00 & 1.91 & 30.56 & 29.32 \\
\hline 1.25 & 1.81 & 32.13 & 27.89 \\
\hline 1.50 & 1.87 & 31.07 & 28.84 \\
\hline 1.75 & 2.05 & 28.50 & 31.44 \\
\hline 2.00 & 4.26 & 14.44 & 62.05 \\
\hline 2.25 & 4.60 & 13.49 & 66.42 \\
\hline 2.50 & 5.02 & 12.47 & 71.85 \\
\hline 2.75 & 2.30 & 25.53 & 35.10 \\
\hline 3.00 & 2.94 & 20.28 & 44.18 \\
\hline 3.25 & 2.95 & 20.22 & 44.31 \\
\hline 3.50 & 2.11 & 27.79 & 32.24 \\
\hline 3.75 & 1.95 & 29.87 & 30.00 \\
\hline 4.00 & 2.01 & 29.06 & 30.83 \\
\hline 4.25 & 1.92 & 30.31 & 29.56 \\
\hline 4.50 & 1.99 & 29.31 & 30.57 \\
\hline
\end{tabular}

\section{Summary}

Presented are three methods used for the calculation of permeability of hard coals including:

1) slug test method and INiG - PIB method which uses bottomhole pressure for the calculation of permeability and skin effect,
2) method which uses water pump capable for maintaining the constant flow rate,

3) method which uses gas pressure decay time for the evaluation of permeability. 
The mathematical models which stand behind each method are presented in appropriate references given at the end of this paper.

The slug test method and INiG - PIB methods are used worldwide in the oil and water industry and are considered as reliable tools for the evaluation of permeability and skin effect. Apart from the INiG - PIB method, the method no. 3 deserves special attention, because it is cheap, easy to run and capable for usage in horizontal drainage wells. The evaluation of permeability doesn't take much time.

Special equipment is required to use methods (2) and (3). They were tested in a limited number of horizontal drainage wells in one of the Polish coal mines. The results are similar to those obtained in laboratory.

\section{Nomenclature}

$p_{D}-$ dimensionless pressure

$t_{D}-$ dimensionless time

$t$ - time [min]

$K$ - coal matrix permeability [mD]

$k_{S}$ - permeability of wellbore zone [mD]

$h$ - thickness of reservoir [m]

$g-$ acceleration of gravity $\left[\mathrm{m} / \mathrm{sek}^{2}\right]$

$\rho$ - fluid density $\left[\mathrm{g} / \mathrm{m}^{3}\right]$

$r_{c}-$ internal tubing radius [m] $r_{0}-$ well radius $[\mathrm{m}]$

$\mu$ - fluid viscosity [cP]

$\varphi$ - porosity

$c_{t}$ - total compressibility $\left[\mathrm{MPa}^{-1}\right]$

$S$ - skin factor

$u$ - root of equation (17)

$p_{i}$ - bottom hole pressure at beginning of flow [MPa]

$p_{0}-$ initial reservoir pressure [MPa]

$p_{d}$ - time dependent bottom hole pressure $[\mathrm{MPa}]$

Please cite as: Nafta-Gaz 2018, no. 6, pp. 443-450, DOI: 10.18668/NG.2018.06.04

Article contributed to the Editor 12.02.2018. Approved for publication 23.03.2018.

The article was written on the basis of a research work entitled: Testy hydrodynamiczne: Metodyka interpretacji testów dla oceny parametrów zbiornikowych pokładów węgli w otworach pionowych i poziomych - INiG - PIB work commissioned by the Ministry of Science and Higher Education; order no.: 14/SI/17, archival number: DK-4100-1/17.

\section{Literature}

[1] Aquilera R., Artindale J.S., et.al. Horizontal Wells, Gulf Publishing Co., Houston 1991, vol. 9.

[2] Dake L.P.: Fundamentals of reservoir engineering. Elsevier, Amsterdam 1978.

[3] Holditch S.A., Ely J.W., Semmelbeck M.E., Carter R.H., Hinkel J., Jeffrey R.G.: Enhanced recovery of coalbed methane through hydraulic fracturing. SPE 18250 , Proc. $63^{\text {rd }}$ Ann. Tech. Conf., Houston 1988, 689 p.

[4] Koenig R., Schraufnagel R.A.: Application of the slug test in coal bed methane testing. Paper 8743. Proceedings of the 1987 International Coalbed Methane Symposium, Tuscaloosa, University of Alabama, 16-19.11.1987.

[5] Nierobisz A.: Sonda areometryczna jako narzędzie do badania szczelinowatości górotworu. Przegląd Górniczy 2014, vol. 70, no. 3, pp. 65-70.

[6] Ramey H.J., Agarval R.G., Martin J.: Analysis of slug test data or DST flow period data. Journal of Canadian Petroleum Technology, vol. 14, no. 3, pp. 37-47.

[7] Sabet M.A.: Well test analyses. Gulf Publishing Company, 1981.

[8] Szpunar T.: How to compute permeability and skin factor of the low pressure water zones. Journal of Canadian Petroleum Technology 2001, vol. 40, no. 7, pp. 1-7.

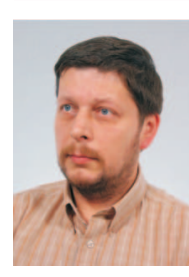

Paweł BUDAK M.Sc. Eng.

Senior Science and Research Specialist

Head of the Department of Petroleum Engineering

Oil and Gas Institute - National Research Institute

ul. Lubicz 25 A

31-503 Kraków

E-mail: pawel.budak@inig.pl
[9] Szpunar T.: Interpretacja krzywych przyplywu i odbudowy ciśnienia $w$ odwiercie ze szczelina poziomą. Nafta-Gaz 1993, no. 1, pp. 11-28.

[10] Szpunar T.: Interpretacja wyników badań hydrodynamicznych w odwiertach poziomych. Nafta-Gaz 1992, no. 9, pp. 229-234.

[11] Szpunar T., Budak P.: Analityczno-graficzny sposób interpretacji danych testu przyptywu cieczy do rurowego próbnika zloża oraz porównanie wyników z otrzymanymi metoda slug test. Nafta-Gaz 2015, no. 2, pp. 77-86.

[12] Szpunar T., Budak P.: How to assess the depth of permeability impairment of the well-bore zone using DST flow period data. Journal of Canadian Petroleum Technology 2012, vol. 51, no. 3, pp. 215-222.

[13] Szpunar T., Budak P.: Prosta metoda określania przepuszczalności poktadów wegla w warunkach kopalnianych. Nafta-Gaz 2016, no. 12, pp. 1054-1062, DOI: 10.18668/NG.2016.12.07.

[14] Szpunar T., Budak P.: Zastosowanie sondy areometrycznej do pomiaru przepuszczalności in-situ za pomoca sprężonego gazu. Nafta-Gaz 2017, no. 12, pp. 935-942, DOI: 10.18668/NG.2017.12.04.

[15] Zuber M.B. et al.: The use of simulation and history matching to determine critical CBM reservoir properties. SPEJ, Denver, Colorado, May 1987.

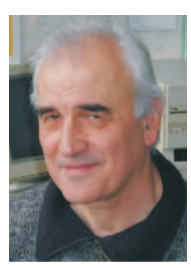

Tadeusz SZPUNAR PhD Eng.

Assistant Professor

Department of Petroleum Engineering

Oil and Gas Institute - National Research Institute

ul. Lubicz 25 A

31-503 Kraków

E-mail: tadeusz.szpunar@inig.pl 